\title{
Leadership in Destination Management: Its Implications in a Systemic Approach
}

\author{
Valentina Della Corte ${ }^{1}$, Giovanna Del Gaudio ${ }^{1} \&$ Alessandra Iavazzi ${ }^{1}$ \\ ${ }^{1}$ University of Naples Federico II, Naples, Italy \\ Correspondence: Valentina Della Corte, Dept. of Economics, Management, Institutions, University of Naples \\ Federico II, Naples 80126, Italy. E-mail:valentina.dellacorte@unina.it
}

Received: November 5, 2013

Accepted: December 13, 2013 Online Published: February 25, 2014

doi:10.5539/jms.v4n1p194

URL: http://dx.doi.org/10.5539/jms.v4n1p194

\begin{abstract}
This paper aims at understanding the existing links between leadership and governance in destinations. The research emphasizes the process through which a subject becomes a pivotal actor in a systemic approach. Once the pivotal actor is legitimated, it is important to verify the relationship between successful leadership and governance choices and configurations.

The research uses a comparative case study analysis on destinations in which one specificactor-that can be entirely public, public-private or totally private-assumes the leadership in order to define the strategic orientation of the local actors and to coordinate them in order to promote destination development.

This research clarifies the main steps that can legitimate a pivotal subject in a destination and the main leadership's governing choices that allow to manage a destination in a systemic approach.

The paper tries to single out and define the links between leadership and governance choices, in order to get to the main aspects of destination management leadership at both a systemic and an individual level of analysis.
\end{abstract}

Keywords: leadership, destination management, governance, destination leadership

\section{Introduction}

\subsection{The Issue of Governance and Leadership in Destination Management}

The issue of governance in tourism field has been analyzed since the 90's (Penny Wan, 2013). The complexity of this topic has enabled the development of numerous contributions that have focused their attention on different features characterizing the concept of governance.

Some authors studied the different types of governance (Erkus-Öztürk \& Eraydın, 2010; Hall, 1994; Timothy, 1999; Caffyn \& Jobbins, 2003), identifying policy and planning networks and self-regulating networks as the two main typologies. Within networks' studies, underling the relationship with the issue of governance, scholars (Beaumont \& Dredge, 2010; Hall, 2011) emphasize the distinction between council-led network, a participant-led community network, and a local tourism organization-led industry network.

Others (Nordin \& Svensson, 2007; Hjalager, 2002) question about the governance models and, hence, on the existence of different forms of governance as well as on the related involvement for the stakeholders that compose the structure.

In the light of governance models, there are some studies highlighting the paths of governance creation and development as well as the role of leading stakeholders (Strobl \& Peters, 2013; Presenza \& Cipollina, 2010).

Furthermore, governance literature in tourism field has adopted different theoretical lens that can regard the strategic profile of governance (strategic management), the organizational aspects of governance such as values and practices (organizational behavior) as well as the institutional features of governance (corporate governance) In this direction, the present work studies the issue of governance through a systematic literature review that categorizes the contributions according to the different theoretical lens and their main contents in order to understand what are the main discussed features within the academic studies and whether there are some gaps within the referring literature. Starting from the gaps in the literature, it gives interesting hints on governance and destination leadership's relationships. 


\subsection{Theoretical Background}

The importance of the territory in the field of destination management is twofold: it has to be conceived in the light of natural and man-made resources that characterize the local territory as well as the system of socio-cultural factors, developed within a specific context thanks to the activation of inter-subjective relationships among different actors (Della Corte \& Sciarelli, 2012).

The relational dynamics, generated in a specific territory, support the creation of governance structures able to pull an innovative process for destination development.

According to some scholars (Penny Wan, 2013; Hall, 2011), the term governance appeared in tourism field at the beginning of the $90 \mathrm{~s}$, when the issue of sustainable tourism began to emerge in the management of a destination. Consequently, the necessity to balance different stakeholders' interests requires an adequate governance structure, able to outline the strategic plans for a sustainable development and to satisfy the expectations of the stakeholders directly or indirectly involved in destination management.

Starting from its origins, one of the first definitions of governance dates back to 1999, when Trousdale (p. 842) claimed that governance is "the ability to coordinate the aggregation of diverging interests to promote policy, projects, and programs that credibly represent the public interests". In a more recent study on the issue, governance is defined as "a diverse set of governing elements and modules acting together on different spatial levels, as well as the procedure of a collective agency coordinating stakeholders and organizations in order to achieve common objectives" (Strobl \& Peters, 2013, p. 60).

The comparison between these two definitions highlights the importance of coordination among different stakeholders in order to valorise and promote the destination and its tourist products. The newness, sprung out in the last decade, concerns the spatial level (geographic scale of application) and the related field of competences.

More precisely, the spatial level, according to the closeness between the governance organization and the system of tourism offer, defines the centralization or the decentralization of the governance itself.

Some scholars agree (Van Lindert \& Nijenhuis, 2002; Yüksel, Bramwell, \& Yüksel, 2005; Turner \& Hulme, 1997) on the current tendency towards the activation of decentralized forms of governance. The choice of decentralization in some countries like Italy, established by National Governmental Authorities, ratifies the transition from central to local government in terms of tourism policies and of the relative area of competence. Nowadays, this type of governance, conceived in a managerial view, carries with itself a traditional planning perspective. From here, it comes out that an effective governance must be able to adopt a managerial perspective that gradually and/or rapidly takes distance from traditional key planning.

Yüksel et al. (2005) distinguish between centralized and decentralized governance. Centralization refers to the existence of central governance institutions responsible for tourism planning at the level of country system while decentralization concerns the proximity of the governance entity with the local system of tourism offer.

The decentralization and, hence, the concentration of decision making at a regional rather than at a local level has led to the development of new forms of collaboration such as partnerships, clusters and innovation systems (Nordin \& Svensson, 2007).

The issue of networks' governance is more complex than ever due to the increasing "fluidity" and "hybridity" of networks in the global competitive environment as well as to the increasing development of more informal and relational communication flows (Yüksel et al., 2005).

Fluidity and hybridity are linked to (Nordin \& Svensson, 2007):

$\checkmark$ both the complexity and the plurality of the involved actors in the process of destination management taking into account the satisfaction of their different interests;

$\checkmark \quad$ the coexistence of public and private bodies and the decision to establish related roles and positions;

$\checkmark \quad$ the identification of a pivotal actor that, in many contexts, is not well defined.

Literature on tourism governance is fragmented, due to the existence of contributions focused on different aspects of governance.

As summarized in table 1, contributions on tourism governance appear focused on different aspects.

Some scholars (Nordin \& Svensson, 2007) highlight the importance of partnerships, clusters and innovation for the destination management in order to create a systemic offer as well as the governance's mechanisms that can facilitate this process. 
Others authors (Erkus-Öztürk \& Eraydın, 2010) focus their attention on the leading organization, whose role is of primary importance in the decision-making process for the definition of strategies leading to global and radical changes. In the same direction, Hultman and Hall (2012) conceive the governance as a social structure, in its different forms (public, private, etc.), able to aggregate various stakeholders.

In this direction, some studies (Krutwaysho \& Bramwell, 2010) identify and explain the governance hierarchy that can be either centralized or decentralized and bottom-up rather than top-down, linked to the degree of control of the leading actor over the other stakeholders in the network.

Both centralization and decentralization represent the first key issues within governance literature (Trousdale, 1999) since the tendency of early works was to study the institutional features of governance, studying the different roles in destination management according to geographic criteria (local, regional and national).

More recent works (Penny Wan, 2013) have underlined the existence of different approaches to study governance and, more precisely, concern the role of political economy and institutional approaches to governance. These two approaches conceive governance as affected by politics, in terms of political-economic opportunities or threats, and institutional features, such as the identification of pivotal actor/s, the decision of shared rules within the network as well as other organizational arrangements.

The development of this topic has viewed, in some cases (Paraskevas, 2013), the use of the concept of governance in order to examine specific destination management contexts such as crisis management. Hence, the concept of governance seems, in today's academic context, to be exploitable also in crisis destination management, overcoming the classical perspective connected with the corporate governance.

Indeed, from the analysis of these contributions it comes out that scholars have used corporate governance as the main theoretical lens since, over the years, they have questioned about the different forms of governance. Furthermore, works on the strategic profile as well as the on organizational aspects of governance (Penny Wan, 2013; Erkus-Öztürk \& Eraydın, 2010) emerge in the last period, integrating the dynamics and the contents of corporate governance.

Table 1. Literature review on destination governance

\begin{tabular}{|c|c|c|c|c|c|}
\hline Author/s & Year & Main focus & $\begin{array}{l}\text { Methodological } \\
\text { approach }\end{array}$ & Theoretical lens & Governance and leadership \\
\hline $\begin{array}{l}\text { Nordin and } \\
\text { Svensson }\end{array}$ & 2007 & $\begin{array}{l}\text { This paper deals with partnerships, clusters } \\
\text { and innovation systems from a governance } \\
\text { perspective }\end{array}$ & Empirical & $\begin{array}{l}\text { Corporate } \\
\text { governance }\end{array}$ & $\begin{array}{l}\text { “...governance implies less } \\
\text { control and predictability, no } \\
\text { self-evident leadership and no } \\
\text { given hierarchy" (p.32). }\end{array}$ \\
\hline $\begin{array}{l}\text { Erkus-Öztürk } \\
\text { and Eraydın }\end{array}$ & 2010 & $\begin{array}{l}\text { This paper aims to contribute to previous } \\
\text { literature by analysing together governance } \\
\text { networks and literature on sustainable } \\
\text { development, and by providing empirical } \\
\text { findings that highlight the importance of } \\
\text { governance networks in sustainable tourism } \\
\text { development, the importance of different } \\
\text { scales of collaborative governance networks } \\
\text { and the role of organisation building for } \\
\text { environmentally sustainable tourism } \\
\text { development in Antalya (p.113). }\end{array}$ & Empirical & $\begin{array}{l}\text { Corporate } \\
\text { governance/ } \\
\text { Organizational } \\
\text { behaviour }\end{array}$ & $\begin{array}{l}\text { "Common debates have covered } \\
\text { the conditions and stages of } \\
\text { collaboration,learning and } \\
\text { innovation in collaboration, the } \\
\text { relevance of company size and } \\
\text { leadership in the collaboration" }\end{array}$ \\
\hline Trousdale & 1999 & $\begin{array}{l}\text { "Better governance should clearly delineate } \\
\text { local, regional and national roles and } \\
\text { incorporate community input to mitigate } \\
\text { against the adverse effects of tourism } \\
\text { development while maximizing benefits" } \\
\text { (p.840) }\end{array}$ & $\begin{array}{l}\text { Empirical } \\
\text { (case study) }\end{array}$ & $\begin{array}{l}\text { Corporate } \\
\text { governance }\end{array}$ & $\begin{array}{l}\text { "Political and community } \\
\text { leadership must come together to } \\
\text { incorporate the concept of } \\
\text { governance into systematic } \\
\text { management of the island" (p. } \\
861 \text { ). }\end{array}$ \\
\hline $\begin{array}{l}\text { Yim King } \\
\text { Penny Wan }\end{array}$ & 2013 & $\begin{array}{l}\text { This study compares the governance of the } \\
\text { two SARs in China, Hong Kong and } \\
\text { Macao, with particular reference to their } \\
\text { tourism planning (p. 164). }\end{array}$ & Empirical & $\begin{array}{l}\text { Corporate } \\
\text { governance/ } \\
\text { Strategic } \\
\text { management/ } \\
\text { organizational } \\
\text { behaviour }\end{array}$ & - \\
\hline
\end{tabular}




\begin{tabular}{|c|c|c|c|c|c|}
\hline $\begin{array}{l}\text { Hultman and } \\
\text { Hall }\end{array}$ & 2012 & $\begin{array}{l}\text { Using governance theory to identify } \\
\text { stakeholder relations, it is shown how } \\
\text { tourism makes place through different } \\
\text { governance approaches. }\end{array}$ & Empirical & $\begin{array}{l}\text { Corporate } \\
\text { governance/ } \\
\text { Strategic } \\
\text { management }\end{array}$ & - \\
\hline $\begin{array}{l}\text { Paraskevas, } \\
\text { Altinay, } \\
\text { McLean, } \\
\text { Cooper }\end{array}$ & 2013 & $\begin{array}{l}\text { The paper proposes a framework for the } \\
\text { governance of crisis knowledge in tourism } \\
\text { p. } 130\end{array}$ & Empirical & $\begin{array}{l}\text { Strategic } \\
\text { management }\end{array}$ & $\begin{array}{l}\text { "[...] leadership should have a } \\
\text { facilitating and coordinating role } \\
\text { through the provision of the right } \\
\text { amount of training, knowledge, } \\
\text { resources and support of the } \\
\text { regional and local managers and } \\
\text { employees by teaching them } \\
\text { "how to fish" rather than simply } \\
\text { giving them fish" (pp. 144-145). }\end{array}$ \\
\hline $\begin{array}{l}\text { Krutwayshoa } \\
\text { ndBramwell }\end{array}$ & 2010 & $\begin{array}{l}\text { The paper "seeks to understand the } \\
\text { application of policies in relation to their } \\
\text { socio-economic, political, governance and } \\
\text { cultural contexts" (p.670). }\end{array}$ & Empirical & $\begin{array}{l}\text { Corporate } \\
\text { governance }\end{array}$ & - \\
\hline
\end{tabular}

Source: our elaboration.

Leadership can be analyzed both at an individual and at an organizational level. Some scholars argue that it almost depends on human resources, either at the top of the organization (such as the CEO or the general manager) or at different levels of the organization (Hunt, 1991; Hunter, Bedell-Avers, \& Mumford, 2007). At an individual level, leadership is described as a process that "connects a subject with the organization he affects by allowing him/her examining how subjective, interpersonal and political processes facilitate or inhibit the actualization of an organizational vision" (Prilleltensky, 1999; Marschke, Preziosi, \& Harrington, 2009). It is important to underline the difference between traits and process leadership. When leadership is defined as "a process whereby an individual influences a group of individuals to achieve a common goal" (Northouse, 2012), it refers to interactive events that affect both the leader and the followers rather than tospecific traits or characteristics of the leader. According to the trait perspective indeed there are some personal qualities that distinguish a leader from a non-leader. In some cases, manager and leader converge and the two figures overlap: this is when managers are involved in influencing a group to meet goals or when leaders are involved in planning, organizing, staffing, and controlling (Northouse, 2012). The process is then expressed:

- $\quad$ at an individual level, through the leader's capability in managing and even dominating events;

- $\quad$ at a systemic level, by reaching the objectives through cooperation with others;

- $\quad$ at an organizational level, sharing the concept of leadership through culture, values and style imprinted in all members of the organization.

For what concerns specifically destination management in a systemic approach, leadership has to be explained according to both an individual and a governance level, as shown in figure 1, analyzing:

- $\quad$ the first level, referred to individual capabilities and skills and the entrepreneurial vision;

- $\quad$ the second level, based on coordination and relational capabilities.

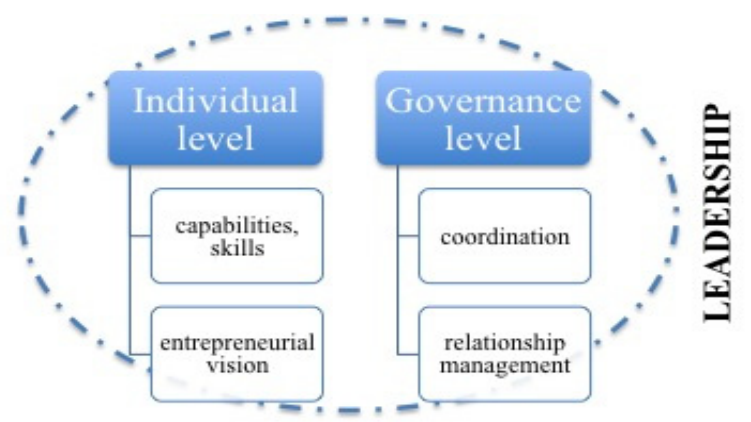

Figure 1. The two levels of leadership

Source: our elaboration. 
When managers are involved in influencing a group to meet goals, they are involved in leadership. When leaders are involved in planning, organizing, staffing, and controlling, they are involved in management. Both processes involve influencing a group of individuals toward coal attainment. So the two constructs overlap (Northouse, 2012).

Since governance implies the coordination of several actors, it is important to underline the link between governance and leadership.

Indeed, there are some organizational factors such as leadership, culture, structure and communication systems (Schein, 2006) that influence the governance itself.

First of all, the concept of leadership, according to some authors (Krutwaysho \& Bramwell, 2010; Della Corte, 2009; Sciarelli, 2007), either top-down or bottom-up, must integrate and enrich itself with specific contents in governance choices. An effective leadership is the "imperative to coordinate the wide range of diverging concerns" (Trousdale, 1999). Hence, that coordination, so much proclaimed in the definitions of governance, represents the trait d'union between governance and leadership.

If governance implies coordination capabilities, leadership plays a key role in influencing and directing the decision policies as well as the strategic actions of the destination. At a destination level, collaboration in governance processes allows to identify and pursuit unforeseen opportunities for mutual gain (Sabel, 1994; Biggart \& Beamish, 2003). This process is favoured by mutual history and trust among participants, a shared sense of urgency, interdependence and future interactions, a clear distribution of authority and entrepreneurs or conveners willing to pay the costs to initiate collective action (Page, 2010).

The existence of various actors with different objectives can be a threat for the governance of the destination since they pursue their own interests without necessarily having common goals. For this reason, leadership and governance are strictly linked. From this point of view, the question becomes: what is the process that determines leadership and leading actors within a network? From our point of view, a leader is a subject (individual, organizational, public or private), which performs a set of functions through which he/she asserts his/her leadership (La Bella, 2010). In particular, a leader establishes his/her own vision, shaping possible and desirable future. Then, he/she takes a position and communicates his/her own set of values and ideas to the community. Furthermore, he/she has to rightly address the available resources in order to gain the objectives, taking care of the overall problems that can occur. Since the context is uncertain, the leader has to demonstrate his/her ability in solving problems with creativity, more as a problem finder than just as a problem solver.

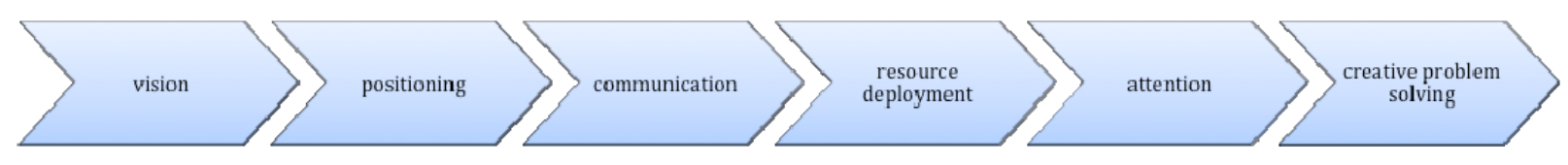

Figure 2. The different functions performed by a leader

Source: our elaboration from La Bella, 2010.

The overall functions indicated in the figure imply the presence of a pivotal actor assuming a leadership role within the system in order to ensure the correct development of the activities. These functions primarily concern the territorial marketing initiatives, in terms of investments, valuing and promotion of the area and coordination of the local actors (Della Corte, 2009). In case of a top-down process, the pivotal actor is the promoter of the activities; when the process is bottom-up, the actors of a destination create a spontaneous aggregation in order to carry out specific management and marketing initiatives and policies. In both cases, the aggregation implies that a Destination Management Organization heads the group to common goals. This actor has to show its leadership capabilities in order to be designed as that able to cover complex governance functions such as planning, coordination, support, monitoring, promotion and commercialization. Furthermore, the DMO has to demonstrate that it has the overall resources that are necessary to achieve the strategic goals. According to the leadership principles, a destination needs to be managed in strategic terms for at least three main reasons:

- the first function of a leader is to create a vision and then to share it to the related organizations; similarly, a DMO creates and shares a systemic vision for the development of the destination;

- at a destination level, a leadership approach can favour stakeholders' commitment and participation in 
tourism activities and in promotion policies;

- a leading actor can stress the attention on strategic tourism management.

It is important to understand which is the role of public and private actors such as Regional Tourism Organisations and/or Local Tourism Organisations in supporting this development with reference to Local, Regional and National Government, as well as to the overall industry and community.

For these reasons, the paper goes on with a comparative case study analysis in which several Italian and international city destinations are analysed and compared.

Coordinated action between public and private organisations brings to more successful tourism planning, management, marketing, product development, training and education. Public / private partnerships allow for communication between all stakeholders and assist in identifying strategies and mechanisms to achieve sustainable tourism development. These partnerships must be developed for mutual benefit to be effective.

For the aim of this paper, a further step is necessary. Despite the studies focusing on the meanings and contents of leadership (Burns, 1978; La Bella, 2010) and governance (King \& Wan, 2013; Hultman \& Hall, 2012; Krutwaysho \& Bramwell, 2010), there is a lack of contributions exploring how these two issues influence each other. Since leadership occurs in groups (Northouse, 1997), it means that a group accepts to be ruled. Hence, leadership implies governance. On the contrary, the definitions of governance consider the recognition as already given. Hence, governance does not necessarily imply leadership. In some contributions, in fact, the concept of governance implies "less control and predictability, no self-evident leadership and no given hierarchy" (Nordin \& Svensson, 2007), or leadership is intended as a way to "incorporate the concept of governance into systematic management" (Trousdale, 1999). This means that "leadership should have a facilitating and coordinating role through the provision of the right amount of training, knowledge, resources and support of the regional and local managers" (Paraskevas, Altinay, McLean \& Cooper, 2013).

\section{Method}

The main objective of this research is to investigate the existing links between leadership and governance and its implication for the destination development. For this reason, we try to identify some findings starting from a comparative analysis between different destinations.

Yan states that case study is "an empirical inquiry that investigates a contemporary phenomenon in depth and within its real-life context, especially when the boundaries between phenomenon and context are not clearly evident" (Yin, 2011), we apply case study research in order to gain an analysis of the context and processes which helped in applying the theoretical issues to real situations (Cassel \& Symon, 2004).

The research focuses on a comparative case study analysis, highlighting the similarities and differences between different destinations, analyzing and comparing quantitative and qualitative data and giving results on the cases (Cassel \& Symon, 2004).

For each case, we try to understand:

- according to the literature review, which is the approach that emerges (strategic management, organizational behaviour, corporate governance);

- $\quad$ who has an active role in developing networks and partnerships with stakeholders;

- $\quad$ which are the strategic policies in coordinating stakeholders and in focusing on strategic resources;

- $\quad$ if they are able to develop clear governance and operational structures;

- $\quad$ which are the strategic opportunities for destination development and marketing.

Thus, the empirical phase concerns the study of several destinations in which pivotal actors allow the tourist development. Barcelona, London, Paris, New York, Sydney and Turin have been chosen because of the strategic role of their pivotal actors in affirming them as must-see destinations. For each of them, we try to understand:

- $\quad$ which was the process that led to the creation of a DMO within the destination;

- $\quad$ which is the pivotal actor and in which way it promotes the coordination of the different stakeholders;

- $\quad$ which is the governance structure it adopts and which are the main governance actors;

- with which process (top-down or bottom-up) the DMO is created and what kind of configuration it has.

\section{Results}

Stating that, in a systemic approach, a pivotal actor is always required, leadership is expressed in the 
competences and capabilities this actor puts in place for the development of a destination. So, when the pivotal actor assumes the lead function, he/she rules groups toward accomplish some tasks or end. Since governance does not depend on the group, the empirical research focuses on the governance aspects.

Data are collected consulting the destinations' annual reports, strategic plans and official websites and synthesized in the table 2 for the comparison.

Table 2. The analysed destinations and their governance

\begin{tabular}{|c|c|c|c|c|c|}
\hline & Creation process & $\begin{array}{l}\text { Pivotal } \\
\text { actor }\end{array}$ & $\begin{array}{l}\text { Strategic policies for } \\
\text { coordination }\end{array}$ & Governance structure & Governance form \\
\hline Barcelona & $\begin{array}{l}\text { Turisme de Barcelona was } \\
\text { founded in } 1993 \text { with the } \\
\text { involvement of local } \\
\text { government and the } \\
\text { business world that hold an } \\
\text { equal share in the } \\
\text { organisation }\end{array}$ & $\begin{array}{l}\text { Turisme de } \\
\text { Barcelona }\end{array}$ & $\begin{array}{l}\text { a) to reconcile } \\
\text { tourists/local community; } \\
\text { b) to ensure the } \\
\text { geographical and } \\
\text { multisectorial distribution } \\
\text { of tourism; } \\
\text { c) to strengthen the } \\
\text { public-private promotional } \\
\text { model. }\end{array}$ & $\begin{array}{l}\text { Chamber of Commerce, } \\
\text { Barcelona Municipal Council, } \\
\text { Barcelona } \\
\text { PromocionFoundation }\end{array}$ & $\begin{array}{l}\text { Bottom-up } \\
\text { Consortium }\end{array}$ \\
\hline London & $\begin{array}{l}\text { London \& Partners was } \\
\text { funded in } 2011 \text { by the } \\
\text { Mayor of London and a } \\
\text { network of commercial } \\
\text { partners. }\end{array}$ & $\begin{array}{l}\text { London \& } \\
\text { Partners }\end{array}$ & $\begin{array}{l}\text { - taking greater advantage } \\
\text { of synergies across our } \\
\text { promotional areas; } \\
\text { - building strategic } \\
\text { partnerships with national } \\
\text { agencies, businesses and } \\
\text { key players; } \\
\text { - raising more private } \\
\text { funding to supplement our } \\
\text { public grant, by delivering } \\
\text { more value } \\
\text { to partners and securing } \\
\text { new revenue streams }\end{array}$ & $\begin{array}{l}\text { Major of London, some } \\
\text { commercial partners }\end{array}$ & $\begin{array}{l}\text { Top-down } \\
\text { Non-profit public } \\
\text { private partnership }\end{array}$ \\
\hline New York & $\begin{array}{l}\text { NYC\&Co. was created in } \\
2006 \text { including NYC \& } \\
\text { Company, NYC Big Events } \\
\text { and NYC Marketing in a } \\
\text { unique pivotal actor. }\end{array}$ & NYC \& Co. & & $\begin{array}{l}1900 \text { companies (tourism } \\
\text { firms, institutions, } \\
\text { government, universities) }\end{array}$ & $\begin{array}{l}\text { Bottom-up } \\
\text { Non-profit private } \\
\text { company }\end{array}$ \\
\hline Sydney & $\begin{array}{l}\text { The New South Wales } \\
\text { (NSW) Government } \\
\text { established Destination } \\
\text { NSW (DNSW) as a } \\
\text { statutory authority in July } \\
2011 \text { to support growth in } \\
\text { the state's tourism and } \\
\text { events sectors. }\end{array}$ & $\begin{array}{l}\text { Destination } \\
\text { NSW }\end{array}$ & $\begin{array}{l}\text { - increase industry } \\
\text { stakeholder and customer } \\
\text { engagement } \\
\text { - deliver value in our } \\
\text { partnership/co-operative } \\
\text { programs } \\
\text { - attract and retain the best } \\
\text { staff and build staff } \\
\text { capacity and capabilities }\end{array}$ & Region, private companies & $\begin{array}{l}\text { Top-down } \\
\text { No-profit public } \\
\text { private partnership }\end{array}$ \\
\hline Turin & $\begin{array}{l}\text { Turismo Torino e Provincia } \\
\text { was created in } 2007 \text { with the } \\
\text { involvement of ATL1 } \\
\text { "Turismo Torino", ATL2 } \\
\text { "Montagnedoc" and ATL3 } \\
\text { "Canavese e Valli di Lanzo } \\
\text { and involved Torino } \\
\text { Convention Bureau in } 2010 .\end{array}$ & $\begin{array}{l}\text { Turismo } \\
\text { Torino e } \\
\text { Provincia }\end{array}$ & & Consortium & $\begin{array}{l}\text { Bottom-up } \\
\text { No-profit public } \\
\text { private partnership }\end{array}$ \\
\hline
\end{tabular}

Source: our elaboration.

\section{Discussion}

Recalling the theoretical premise that conceives the leadership process as expression of an overlapping perspective encompassing three levels (individual, systemic and organizational), this paper explores the 
existence of these components through the selected cases. It starts from the identification of the pivotal actor to after decompose the governance structure, understanding leadership processes and mechanisms.

Furthermore, from the theoretical reflections sprang out that coordination is a match point between governance and leadership. There are others specific features belonging to both these issues. More precisely, aspects such as organizational mechanisms as well as strategic profile have to be analyzed in the light of an overlapping perspective between governance and leadership. This is the reason why this paper categorizes (see Table 2) some destinations according to some parameters that helps in understanding the two issues.

In the selected cases, governance models are very differentiated. A first step concerns the identification of its nature in terms of public or private actors involved. Some destinations have been created thanks to public-private partnerships (Barcelona, London, Turin) with different legal framework (i.e., consortium, company) while other destinations (Sydney) show a public or a private (New York) configuration. A clarification is necessary since, even in the case where the governance leading actor is mainly public, the collaboration between firms and institutions appears very strong and profitable such as the case of Sydney.

The creation process of the pivotal actor is generally bottom-up (New York, Barcelona, Turin) since it represents an initiative launched by different actors through, for example, chamber of commerce or trade association.

At this point, a question comes out: How does leadership emerge and insert itself within the issue of governance?

As theory underlines, the main functions of leadership concern establishing a vision, addressing available resources, exploiting the competences of the actors of the network, spreading a set of values in order to be shared, showing the right knowledge and ability in particular situations such as in the case of destination crisis.

London\&Partners, for example, states that its vision is "That London will be recognised globally as the best big city on earth". In order to do this, it works in partnership with different actors in London and is organized in teamwork for each specific target (business and leisure tourism, higher education, major events and so on) to satisfy each specific need.

With reference to shared values, ConsorcioTurisme de Barcelona has showed its ability in the creation of a unique brand identity called "BCN". The diffusion of shared practices and values by the governance actor has allowed the creation of different umbrella brands such as $\mathrm{BCN}$ culture, $\mathrm{BCN}$ gastronomy that aim at strengthen its different tourist products.

Destination NSW, as regards the systematization of available resources and the exploitation of existing competences, creates a systemic offer for the main tourist products of the destination. This is the case of the "food \& wine" product where the ability deployed by the leading actor is showed through the coordination among actors involved in the management of destination's amenities, helping these actors in overcoming the classical concept of competition (the offer of the involved firms is similar). Indeed, the governance entity has been able to spread the sense of coopetition (cooperation + competition - Dagnino\&Padula, 2002) for the creation of a strong gastronomic identity, becoming one of the "great dining destinations" (Note 1).

Turismo Torino e Provincia has been able to erase Turin's image of "industrial city". Leveraging on its history and cultural resources, the DMO has "reinvented" the concept of the city, transforming it in a destination with high innovation capabilities, heart of cultural activities and tourism attractions.

As regards the institutional aspects of the governance, scholars (Van Lindert \& Nijenhuis, 2002; Yüksel et al., 2005; Turner \& Hulme, 1997) have emphasized centralization and decentralization as one of the main topics within the referring literature and have underlined the global tendency around the orientation towards decentralized model.

Turisme de Barcelona, London \& Partners, NYC \& Co, Destination NSW and Turismo Torino e Provinciademonstrate the adoption of a decentralization model that allows a better focus on destination's tourism product and the related systematization, promotion and commercialization.

Sydney shows a great example of the tension between centralization and decentralization through the Australian governance model that is conceived according to a network model among different levels (Federal, Regional and Local), allowing so an integrated organization of tourism sector. This configuration provides, at a central level, the existence of a governmental authority (Tourism Australia) responsible for the promotion of the overall tourism product "Australia". There is then a regional government agency, Destination New South Wales that promotes and sustains the tourism development of the state New South Wales (NSW). Within this regional government agency, there are other organizations such as Tourism NSW that with its division VisitSydney, can strategically manage the tourism development of Sydney. 
To summarize, it is clear that these governance models are very different. Sydney, for example, shows a configuration in which the role of the public actor is extremely relevant while New York is developed thanks to the willingness of private actors. These two situations represent a continuum in which it is possible to position other governance models, whose relevant role is assumed from the public-private partnerships (Barcelona, London, Turin) with different legal frameworks (i.e., consortium, company). Thus, even if the configuration models are extremely different, a strong collaboration between firms and institutions represents a key line in these cases, showing a similarity in the leadership.

\section{Conclusions}

This paper explored the concepts of governance and leadership as well as the existence of their interconnections within the literature on destination management both theoretically and empirically. From this analysis, it comes out that the coordination can be conceived as binding agent between governance and leadership. Even if the analysed cases show different governance models in terms of their composition (i.e., public and private actors), coordination is deployed by the governance entity and it springs out an effective leadership, although some scholars state that (Nordin \& Svensson, 2007) leadership cannot be evident. Leadership, in particular, facilitates establishing and sharing vision and addressing available resources necessary to reach a common goal.

In the selected cases, DMOs demonstrate that institutional aspects of governance (i.e., centralization and decentralization, the top-down or bottom-up nature) help in favoring the creation process of a destination, such as in the case of Turin, or the development process of its growth.

\section{References}

Beaumont, N., \& Dredge, D. (2010). Local tourism governance: A comparison of three network approaches. Journal of Sustainable Tourism, 18(1), 7-28. http://dx.doi.org/10.1080/09669580903215139

Biggart, N. W., \& Beamish, T. D. (2003). The economicsociology of conventions: Habit, custom, practice, and routine in marketorder. Annual Review of Sociology, 29, 443-464. http://dx.doi.org/10.1146/annurev.soc.29.010202.100051

Caffyn, A., \& Jobbins, G. (2003). Governance capacity and stakeholder interactions in the development and management of coastal tourism: examplesfrom Morocco and Tunisia. Journal of Sustainable Tourism, 11(2-3), 224-245. http://dx.doi.org/10.1080/09669580308667204

Cassell, C., \& Symon, G. (2004). Essential guide to qualitative methods in organizational research. Thousand Oaks, CA: SAGE Publications.

Della Corte, V., \& Sciarelli, M. (2012). Destination management e logicasistemica. Un confrontointernazionale. Torino, IT: Giappichelli.

Della Corte, V. (2009). Imprese e sistemi turistici: il management. Milano, IT: Egea.

Erkuş-Öztürk, H., \& Eraydın, A. (2010). Environmental governance for sustainable tourism development: Collaborative networks and organisation building in the Antalya tourism region. Tourism Management, 31(1), 113-124. http://dx.doi.org/10.1016/j.tourman.2009.01.002

Hall, C. M. (1994). Tourism and politics, policy, powerandplace. London, Chichester: Wiley.

Hall, C. M. (2011). A typology of governance and itsimplications for tourism policy analysis. Journal of Sustainable Tourism, 19(4-5), 437-457. http://dx.doi.org/10.1080/09669582.2011.570346

Hjalager, A. M. (2002). Repairing innovation defectiveness in tourism. Tourism management, 23(5), 465-474. http://dx.doi.org/10.1016/S0261-5177(02)00013-4

Hultman, J., \& Hall, C. M. (2012). Tourism place-making: Governance of locality in Sweden. Annals of Tourism Research, 39(2), 547-570. http://dx.doi.org/10.1016/j.annals.2011.07.001

Hunt, G. (1991). Leadership: a new synthesis. Park, CA: Sage Newbury.

Hunter, S. T., Bedell-Avers, K. E., \& Mumford, M. D. (2007). The typical leadership study: Assumptions, implications, and potentialremedies. The Leadership Quarterly, 18(5), 435-446. http://dx.doi.org/10.1016/j.leaqua.2007.07.001

Krutwaysho, O., \& Bramwell, B. (2010). Tourism policy implementation and society. Annals of Tourism Research, 37(3), 670-691. http://dx.doi.org/10.1016/j.annals.2009.12.004

La Bella, A. (2010). Leadership. Milano, IT: Apogeo Editore.

Lane, T. D. (1999). IMF-supportedprograms in Indonesia, Korea and Thailand: a preliminary assessment. 
Washington DC: International Monetary Fund.

Marschke, E., Preziosi, R., \& Harrington, W. (2009). Professionals And Executives Support A Relationship Between Organizational Commitment And Spirituality In The Workplace. Journal of Business \& Economics $\begin{array}{lllll}\text { Research } & \text { (JBER), 3(8), } & \text { 33-48. } & \text { Retreived }\end{array}$ http://journals.cluteonline.com/index.php/JBER/issue/view/250

Nordin, S., \& Svensson, S. (2007). Innovative destination governance: the Swedish ski resort of Are. Entrepreneurship and Innovation, 8(1), 53-66. http://dx.doi.org/10.5367/000000007780007416

Northouse, P. G. (2012). Leadership: Theory and practice. Thousand Oaks, CA: SAGE Publications.

Page, D. (2010). Systemicefforts in Georgia to improveeducation leadership. Performance Improvement, 49(3), 11-16. http://dx.doi.org/10.1002/pfi.20132

Paraskevas, A., Altinay, L., McLean, J., \& Cooper, C. (2013). Crisisknowledge in tourism: types, flows and governance. Annals of Tourism Research, 41, 130-152. http://dx.doi.org/10.1016/j.annals.2012.12.005

Presenza, A., \& Cipollina, M. (2010). Analysing tourism stakeholders networks. Tourism Review, 65(4), 17-30. http://dx.doi.org/10.1108/16605371011093845

Prilleltensky, I. (1999). Critical psychology praxis. In M. Montero (Ed.), La Psicologia al fin del siglo (pp. 279-304). Caracas: Sociedad Interamericana de Psicologia.

Sabel, C. F. (1994). Flexiblespecialisation and the re-emergence of regionaleconomies. In A. Amin (Ed.), Post-fordism. A reader (pp. 101-156). Oxford: Blackwell.

Schein, E. H. (2006). Organizational culture and leadership. San Francisco, CA: John Wiley \& Sons.

Sciarelli, S. (2012). Il management dei sistemi turistici locali: strategie e strumenti per la governance. Torino, IT: Giappichelli.

Strobl, A., \& Peters, M. (2013). Entrepreneurialreputation in destination networks. Annals of Tourism Research, 40(January), 59-82. http://dx.doi.org/10.1016/j.annals.2012.08.005

Svensson, B., Nordin, S., \& Flagestad, A. (2005). A governance perspective on destination development-exploring partnerships, clusters and innovationsystems. Tourism Review, 60(2), 32-37. http://dx.doi.org/10.1108/eb058455

Turner, M., \& Hulme, D. (1997). Governance, administration and development: Making the state work. Basingstoke: Macmillan.

vanLindert, P., \& Nijenhuis, G. (2002). Popular participation and the Participatory planning practice in Latin America: some evidence from Bolivia and Brazil. In I. S. A. Baud \& J. Post (Eds.), Realigning actors in a urbanizing world: governance and institutions from a development perspective (pp. 175-196). London, UK: Ashgate.

Yin, R. K. (2011). Applications of case study research. Thousand Oaks, CA: SAGE Publications.

Yüksel, F., Bramwell, B., \& Yüksel, A. (2005). Centralized and decentralized tourism governance in Turkey. Annals of Tourism Research, 32(4), 859-886. http://dx.doi.org/10.1016/j.annals.2004.09.006

\section{Note}

Note 1. http://www.sydney.com/things-to-do/food-and-wine

\section{Copyrights}

Copyright for this articleis retained by the author(s), with first publication rights granted to the journal.

This is an open-access article distributed under the terms and conditions of the CreativeCommons Attribution license (http://creativecommons.org/licenses/by/3.0/). 